\title{
Synthetic Mulches in Organic Hardneck Garlic (Allium sativum subsp. ophioscorodon) Production
}

\author{
Matthew A. Carr ${ }^{1}$ and Kate A. Congreves ${ }^{1, *}$
}

\begin{abstract}
The demand for certified organic garlic (Allium sativum) in Canada is increasing; however, garlic can be challenging to produce organically, as it does not compete well with weeds, requires relatively fertile soils, and is grown in a biennial cropping system. Synthetic mulches have been adopted in organic production as they can be an economical method to improve vegetable production by reducing weed pressure and modifying soil conditions. We hypothesize that garlic quality and overall yield will be improved when using synthetic mulches. In 2017-18, we conducted a randomized complete block design experiment to compare garlic production of black plastic, white plastic, and Kraft paper mulch treatments to a control with no mulch at a certified organic farm in Krestova, British Columbia. We evaluated garlic characteristics associated with yield and quality, changes in soil nutrition, and weed control of the mulch treatments. We found that plastic mulches had the best weed control, and all synthetic mulches increased minimum and maximum bulb diameter, clove count, and yield compared to the control. Mulching materials did not influence soil nitrate concentrations. The results support the hypothesis that synthetic mulches increase the quality and yield of the garlic compared to the control. Our findings suggest that synthetic mulching may be a key component of improving garlic production systems.
\end{abstract}

Keywords: agronomy, horticulture, vegetable crops, sustainable agriculture

\section{Introduction}

There is a large market of opportunity for Canadian garlic producers. This opportunity, however, is undermined by limited research on garlic production for Canadian conditions and practices. There are key agronomic adjustments that could potentially increase grower returns and improve the garlic industry. One of the most controversial practices in garlic production is the use of different mulches and their influence on quality and yields, largely attributed to mixed findings in the literature (Hutchins 1933; Jones and Mann 1963; Engeland 1991; Waterer and Schmitz 1994; Walters 2008). Growers continue to question whether mulching will optimize garlic production

1 Department of Plant Sciences, College of Agriculture and Bioresources, University of Saskatchewan, Saskatoon, SK, Canada *Correspondence: kate.congreves@usask.ca

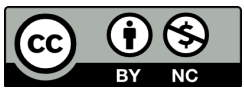

University of Saskatchewan Undergraduate Research Journal Volume 6, Issue 2, 2020

(C) 2020 Matthew A. Carr and Kate A. Congreves. This open access article is distributed under a Creative Commons Attribution Non-commercial 4.0 license. (https://creativecommons.org/licenses/by-nc/4.0/) 
or not, and selection of mulching material is somewhat controversial.

Mulches are protective coverings used to maintain soil moisture, create even temperatures, prevent erosion and control weed growth. From this definition, mulches can be categorized as organic or synthetically derived. Organic material mulches, like straw, have played an important role in organic garlic production due to the lack of alternatives available for economies of scale. Traditionally, small operations used cereal straw mulch to improve winter survival, increase long-term soil organic matter content, and gain the benefits of mulching while keeping the input costs relatively low. Cereal straw mulches can be highly variable in success due to other factors out of the garlic producers' control, including inconsistent weed control and the introduction of new weeds (Kasirajan and Ngovajio 2012). The availability of certified organic cereal straws in southern British Columbia also plays a key role in material selection, as growers often view transportation distances and costs as unsustainable.

Plastic mulches have been popular since their creation. Polyethylene films are cheap to produce, lightweight but durable, resist breakdown, exclude weeds, and provide the most reliable soil temperature modifications and moisture retention. The development of equipment for application and removal has decreased labour requirements, making plastic mulch more attractive to growers. Black plastic mulch is the industry standard as its soil modification attributes benefit the majority of crops, especially high valued warm-season field vegetables. Other colours of plastic mulch have entered the market but have not been readily adopted by growers due to higher costs and growers' reluctance to experiment with new products.

Different colours of mulch create an array of soil modifications. Results from the Snyder et al. (2015) mulch study in Ontario confirms that clear mulches tend to increase the soil temperature the most, white mulches tend to lower root zone temperatures, and black mulches provide an intermediate between the two. These temperature modifications are due to the optical energy absorbance of the individual colours into the soil as well as the effect of mulch on insulating and retaining heat (Ham et al. 1993; Lamont 2005; Snyder et al. 2015).

Weed control varies between colours as well. Opaque films tend to eliminate weed growth due to the physical barrier of the mulch combined with reduced light for photosynthesis (Snyder et al. 2015). Weed control in clear plastic can be an issue in high weed-banked areas because the mulch allows photosynthetic light to pass through, increases temperatures, and retains moisture, which creates a mini-greenhouse effect that promotes weed growth and reduces the expected benefits of the mulch (Waterer 2000, 2010).

Moisture retention is an extremely valuable benefit of plastic mulch. Water conservation in the soil zone under plastic is due to the reduced evaporation of water and vapour flow in the soil-atmosphere interface (Saglam et al. 2017). Since plastic is less permeable, stronger, and less degradable than other naturally sourced materials used for mulching, such as straw or compost, water flow across the soilatmosphere interface is very low, which greatly improves moisture retention in the soil. The moisture retention properties create more consistent conditions for plant growth by mediating soil drying and saturation. The moisture-exclusive effect of the film can also create problems for water infiltration from irrigation and rainfall. For this reason, drip irrigation is most common under plastic mulch. Although moisture retention is an attribute of almost all mulches, plastic is the most efficient for water conservation.

The most significant issue with plastic mulch is its removal and disposal. Organic matter and soil tend to collect on the material, which makes recycling the plastic almost impossible (Steinmetz et al. 2016). Most plastic mulches are disposed of in landfills, burned, illegally dumped, or incorporated into the field soil due to the cost or inaccessibility of recycling (Lamont 2005; Coolong 2010).

Plastic mulches can be used in certified organic systems, but they are often controversial. Their ability to increase yields and decrease costs have attracted growers, but these benefits outweigh the negative impacts for only a small percentage of certified organic growers. Drawbacks to plastic mulch in an organic system include increased economic costs, no return of organic matter, and ethical issues with the disposal of the plastic materials (Steinmetz et al. 2016). Recently developed biodegradable mulches have been prohibited for use in organic systems due to concerns with the incorporation of petroleum-based products into the soil.

Paper mulch is touted as a more sustainable option for synthetic mulching in organic agriculture because it is made from renewable resources, decomposes into the soil, and aligns with the organic, ethical decision to avoid the disposal of plastic materials. These mulches were once popular before the development of polyethylene mulches that provided different benefits to crops. Although paper has its limitations, recent results have shown paper to be a viable alternative to traditional black plastic mulches; for example, paper mulch provides some weed suppression, decreases soil temperatures, retains moisture, and allows water to infiltrate from the mulch surface during sprinkler irrigation or rainfall (Schonbeck and Evanylo 1998; Coolong 2010; Saglam et al. 2017). These benefits are more pronounced in cool-season crops such as garlic.

A significant drawback to paper mulches is the potential for rapid breakdown, resulting in exposed soil surface areas, which minimizes the benefits of mulching (Hutchins 1933). Treatments to paper mulch that improve the resistance to degradation may facilitate their adoption as they reduce excessive biological breakdown during the 
Table 1: Comparisons and considerations of different types of mulch.

\begin{tabular}{|c|c|c|c|c|c|c|c|c|c|}
\hline Mulch & Cost & Application & $\begin{array}{c}\text { Weed } \\
\text { suppression }\end{array}$ & $\begin{array}{l}\text { Soil moisture } \\
\text { retention }\end{array}$ & Permeability & $\begin{array}{l}\text { Soil temperature } \\
\text { modification }\end{array}$ & Disposal & $\begin{array}{c}\text { Renewable } \\
\text { resource }\end{array}$ & $\begin{array}{c}\text { Organic } \\
\text { acceptance }\end{array}$ \\
\hline Straw & $\$ \$$ & Difficult & Variable & Good & & Decrease & Decomposition & & \\
\hline $\begin{array}{l}\text { Black } \\
\text { plastic }\end{array}$ & $\$$ & Easy & Excellent & Excellent & & Increase & Landfill $^{a}$ & & \\
\hline $\begin{array}{l}\text { White } \\
\text { plastic }\end{array}$ & $\$$ & Easy & Excellent & Excellent & & Decrease & Landfill & & \\
\hline Paper & $\$ \$ \$ \$$ & Moderate & Variable & Variable & & Decrease & Decomposition & & \\
\hline
\end{tabular}

growing season and make application easier; however, most of these treatment materials are prohibited in organic agriculture due to their unknown long-term effect on soil. New paper mulches use varying paper thicknesses and plant-based treatments to increase strength, reduce the rate of decomposition, and increase available nutrition with fortified nutrients. Other considerations that limit paper mulching include the immobilization of nitrogen as the mulch decomposes, increased labour to apply and repair, higher cost of material and transportation than plastic mulches, and unreliable soil temperature modification (Coolong 2010).

Overall, each mulching system has benefits and disadvantages. Table 1 provides a comparison between straw, black plastic, white plastic, and paper mulches. While paper appears to be the best synthetic option for organic growers, its high material cost may be prohibitive. Both plastic mulches offer the most efficient soil modification and low material cost; however, their petroleum-based nature and single-use disposal may not meet growers' ethical standards. Straw may also remain important for mulching garlic, but transportation costs and low availability for organic producers can limit its use.

A comparison of these synthetic mulches in garlic production is an important aspect of improving growing practices for organic growers in Canada. We hypothesize that the improved weed control and soil modifications of synthetic mulches will lead to increased quality and overall yield of hardneck garlic in organic farming systems. We analyze the differences in hardneck garlic bulb agronomic traits when produced using different synthetic mulches. Ultimately, the goal of the study is to determine which mulch is best to improve garlic quality and yields. Through this research, we provide initial analysis and indicate factors in garlic production for further study. By evaluating the influences of different synthetic mulching materials, organic growers can make an informed decision to meet their economic and ethical demands.

\section{Materials and Methods}

\section{Field Preparation and Experimental Design}

The trial was conducted from October 2017 to August 2018 at Linden Lane Farms in Krestova, British Columbia, Canada ( $49^{\circ} 4^{\prime} \mathrm{N}, 117^{\circ} 6^{\prime} \mathrm{W}, 615$ m elevation) on a Brunisol with a sandy-loam texture. The site was located on a slight southern slope with a southern windbreak of native pines. The field was originally cattle pasture, and composted manure was applied when the soil was broke for production in 2013 . From 2013 to 2017 , the field was rotated between squash, onions, lettuce, corn, and fallow. Composted manure was also applied in the spring of 2014 and 2015 before planting vegetables. Field preparation occurred on October 7 and 8, 2017. Monthly temperature and precipitation data were recorded for the duration of the trial (Table 2). The site was rototilled to a depth of $15 \mathrm{~cm}$ before bed formation to incorporate previous crop and weed debris. Soil fertility and $\mathrm{pH}$ were collected at the time of field preparation (Table 3). No fertilizers were added during field preparation.

The experiment used a randomized complete block design with four replicates and four mulch treatments (Figure 1). The treatments included 1) black embossed plastic film $(25 \mu \mathrm{m}) ; 2$ ) white on black embossed plastic film $(25 \mu \mathrm{m})$; 3) brown Kraft paper (152 $\mu \mathrm{m})$; and 4) a negative control without mulch.

\section{Mulch Laying}

The whole field consisted of four raised beds, formed with a plastic mulch layer. We established a onemeter buffer zone between treatments within each raised bed row, with two lines of drip irrigation per bed (Figure 1). We applied plastic mulch before planting, as per common practices. The paper mulch was applied after planting because garlic can push through the paper in early spring. We covered the edges of the paper mulch with soil. 
Table 2: Monthly temperature and precipitation data, as reported by Environment Canada (Castlegar Airport, BC).

\begin{tabular}{cccccc}
\hline Year & Month & $\begin{array}{c}\text { Mean Temperature } \\
\left({ }^{\circ} \mathrm{C}\right)\end{array}$ & $\begin{array}{c}\text { Degree Days above } \\
18^{\circ} \mathrm{C}\end{array}$ & $\begin{array}{c}\text { Total Precipitation } \\
(\mathbf{m m})\end{array}$ & $\begin{array}{c}\text { Snowfall } \\
(\mathbf{c m})\end{array}$ \\
\hline \multirow{2}{2017}{} & October & 7.6 & 0 & 60.4 & 0.6 \\
\cline { 2 - 6 } & November & 2.6 & 0 & 103.8 & 35.8 \\
\cline { 2 - 6 } & December & -2.6 & 0 & 70 & 67.6 \\
\cline { 2 - 6 } & January & 0.1 & 0 & 147 & 105.8 \\
\cline { 2 - 6 } & February & -2.6 & 0 & 51 & 68.2 \\
\cline { 2 - 6 } & March & 3.7 & 0 & 62 & 26.8 \\
\cline { 2 - 6 } & April & 7.7 & 0 & 103.4 & 12.8 \\
\cline { 2 - 6 } & May & 16.9 & 20.3 & 50.4 & 0 \\
\cline { 2 - 6 } & June & 16.8 & 22.1 & 50.8 & 0 \\
\hline
\end{tabular}

Table 3: Soil fertility based on 8 randomized sample cores $15 \mathrm{~cm}$ deep across planting area before bed preparation. Testing was done through ALS Global, Saskatoon.

\begin{tabular}{llllll}
\hline Location & pH & Nitrate $(\mathrm{mg} / \mathrm{kg})$ & $\begin{array}{l}\text { Phosphate } \\
(\mathrm{mg} / \mathrm{kg})\end{array}$ & $\begin{array}{l}\text { Potassium } \\
(\mathrm{mg} / \mathrm{kg})\end{array}$ & $\begin{array}{l}\text { Sulfur } \\
(\mathrm{mg} / \mathrm{kg})\end{array}$ \\
\hline Garlic Thesis Plot & 7.39 & 44.0 & 413 & 365 & 18.8 \\
\hline Report Date: October 25 2017 & & & & & 365 \\
\hline
\end{tabular}

\section{Plant Material}

Allium sativum subsp. ophioscorodon 'Krestova Red Russian' was the parent plant material, grown on-site at Linden Lane Farms, due to its long growing history on the farm and its consistent year-to-year yields. Bulbs were selected based on an average diameter of $4 \mathrm{~cm}$ and then cracked manually five days before planting. We culled all visually small or damaged cloves, as per normal production practices. After sorting, we mixed the cloves to randomize the samples before planting.

\section{Planting}

Planting occurred on November 1, 2017. Cloves were planted by hand 5 to $12 \mathrm{~cm}$ deep, with $15 \mathrm{~cm}$ between plants in rows, which created a density of approximately 80 plants per plot. In the plastic mulch treatments, the cloves were planted through holes using a dibbler apparatus for uniform spacing. This dibbler was also used for planting treatment before applying paper mulch.

\section{Irrigation and Fertilization}

Irrigation was applied irregularly due to unplanned issues with the supply line in that location of the farm. No fertigation was applied due to the same supply line issues. Drip irrigation did occur on November 1, 2017, and May 6, May 16, and June 4, 2018. Each irrigation session lasted approximately 2 hours to wet the rooting zone. Irrigation did not occur after June 4, 2018.

\section{Weed Management}

Weed removal was necessary due to increasing competition with the crop. Weeds were managed between beds using a stirrup hoe and walk-behind rototiller on May 22, 2018. Additional manual weeding between beds occurred periodically until harvest. We removed all weeds in 
the beds on July 3,2018 , by cutting at the soil level to avoid disturbing the mulches.

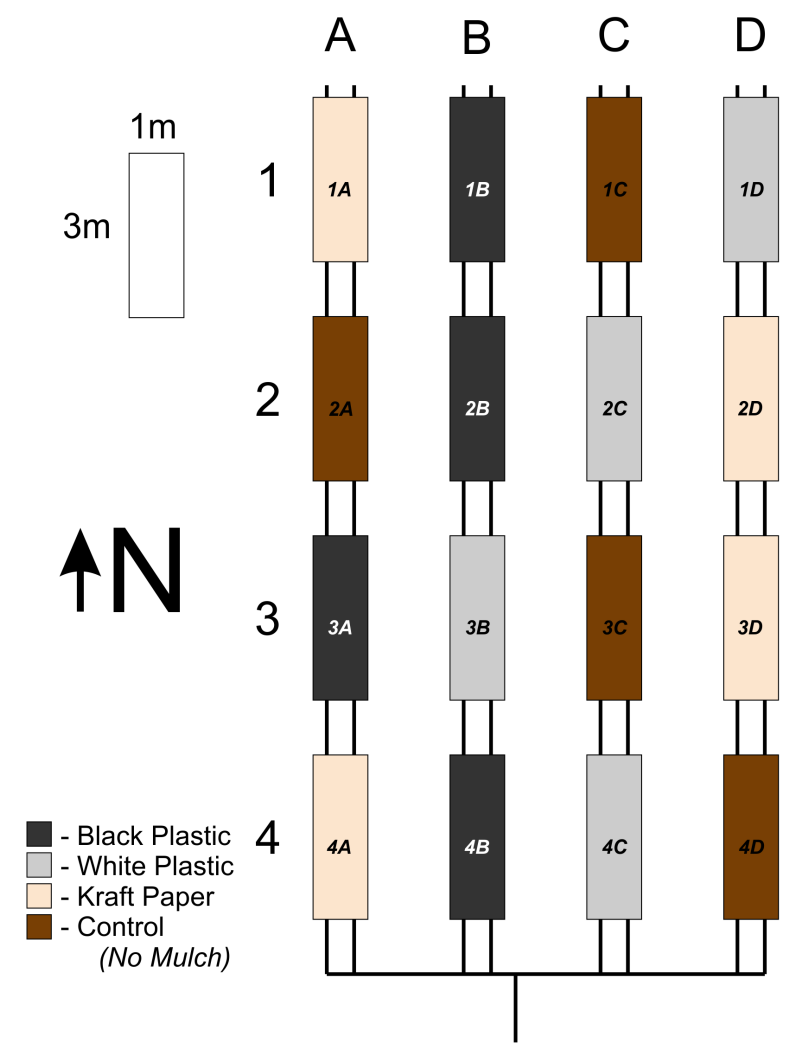

Figure 1: Experimental plot layout. Randomized complete block design with four replications, with replicates arranged perpendicular to the slope of the land. Treatments: Black Plastic, White Plastic, Kraft Paper and Control (no mulch). Black lines show drip irrigation (2 lines per bed).

\section{Crop Management}

There was little management required for the crop. The scapes (flowering stalks) were removed from the plants on August 7, 2018, by cutting the stem at the point of attachment at the highest leaf. Scape removal is a common practice in commercial garlic production.

\section{Sample Collection}

Weed material was collected to compare weed density, population, and biomass data between treatments. We collected weed growth data on July 3, 2018, within randomized $0.5 \mathrm{~m}$ transects of each plot across the beds (Figure 2). To improve data collection within the transect, we manually removed weeds outside of the transect by trimming at the mulch surface.

Weed factors were analyzed from materials collected within randomized $0.5 \mathrm{~m}$ transects per plot. We counted the number of plants per weed species present. The weeds from each section were then cut at soil level and removed into associated pre-weighed bins. The bins of weeds were then placed in a greenhouse to dry for five weeks before being weighed to calculate dry weed biomass. We calculated mulch damage by estimating the percentage of damage within the same $0.5 \mathrm{~m}$ transects per plot (Figure 2).

Soil samples were required for the soil nutrient analyses. Eight randomized soil samples from o to $15 \mathrm{~cm}$ depth were collected and homologized for each plot. The samples were frozen after collection to preserve their integrity before being tested for soil nitrogen levels.

Soil temperatures were collected using a digital thermometer with a probe length of $9 \mathrm{~cm}$ (Figure 3). The probe was inserted into the soil through the mulch randomly at each plot and recorded in degrees Celsius. The temperatures were collected around 7:00 pm, except the June 7 measurement, which occurred at 5:00 pm.

The garlic bulbs were harvested on August 23, 2018. The bulbs were stored in separate plastic mesh bags in a well-ventilated area for final curing until September 2, 2018. After curing, the roots of the bulbs were clipped to the bottom of the cloves. The stems were trimmed to approximately the height of the cloves, and the outer wrappers were removed. The bulbs were then stored in plastic mesh bags in the lab until they were measured for character attributes.

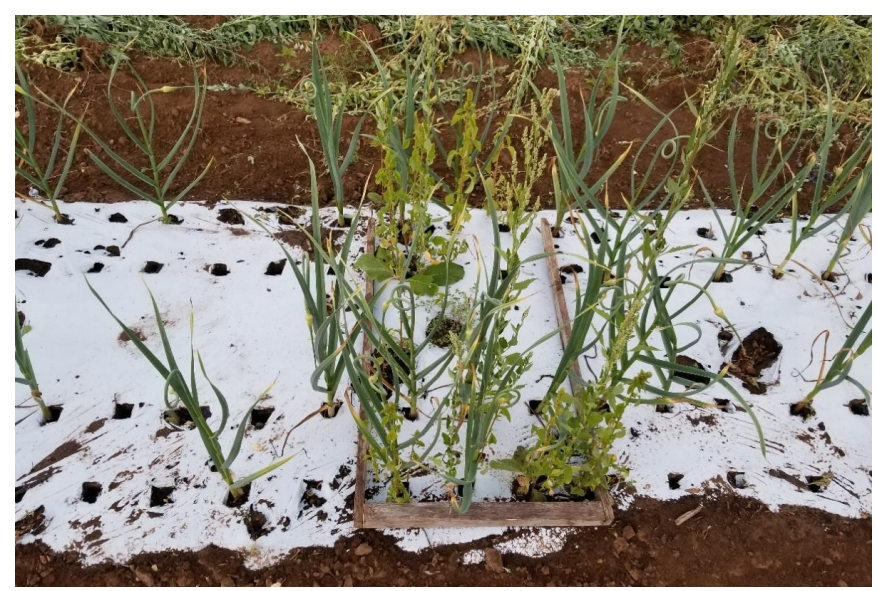

Figure 2: Collection process for weed and mulch damage data on the $0.5 \mathrm{~m}$ transect. Weeds outside the transect were removed to improve weed data collection. Photo credit M. Carr; July 3, 2018.

\section{Sample Processing and Analysis}

After thawing at lab room temperature, soil samples from each plot were tested for available nitrogen concentration using the $\mathrm{KCl}$ method (Maynard et al. 2008). Nitrogen was extracted from $5 \mathrm{~g}$ fresh weight soil samples using $25 \mathrm{ml}$ of extractant. The filtered solution was frozen until colorimetric analysis.

We measured the average minimum and maximum diameters of twenty randomly selected bulbs per plot, using 

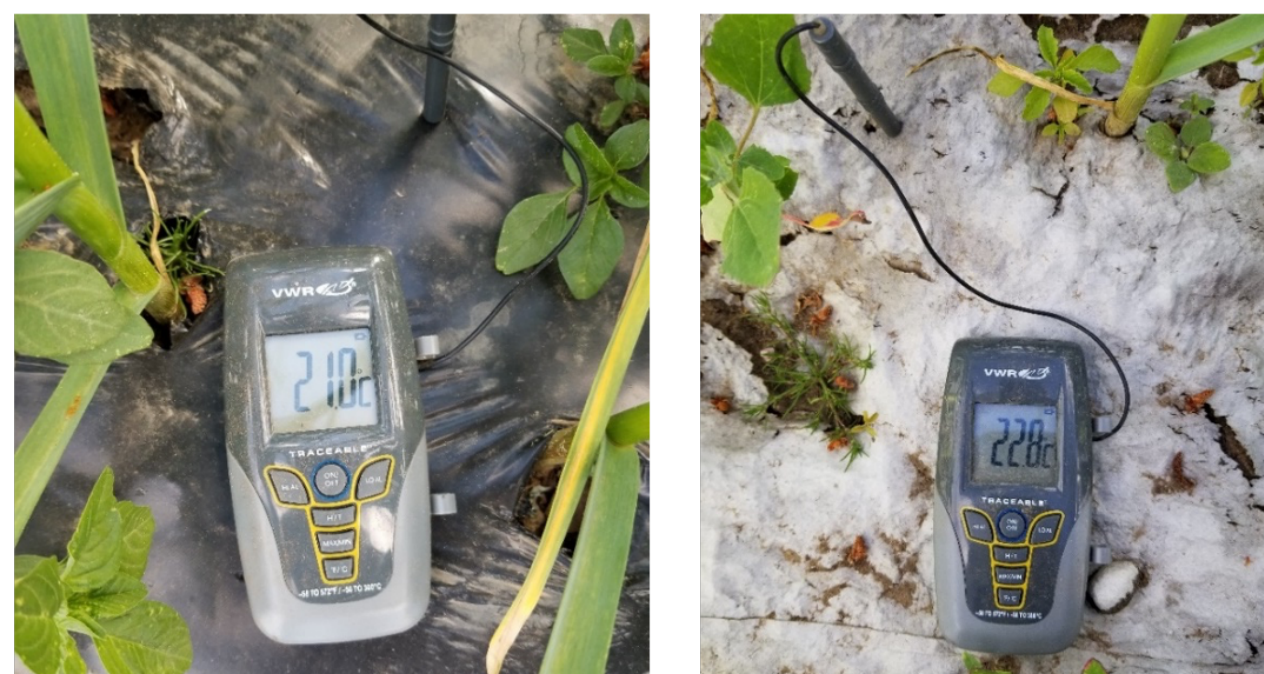

Figure 3: Measuring soil temperature under black plastic and paper mulches. Photo credit M. Carr; June 4, 2018.

a digital metal caliper across the bulb at approximately the midpoint of the cloves (Figure 4: $A$ and $B$ ). We compared clove counts per bulb across treatments. The cloves per bulb were counted manually by inspection (Figure ${ }_{4} C$ ).

The average yield was expressed in tonnes per hectare and calculated based on planting density and average fresh weight of twenty randomized bulbs per plot, at a $90 \%$ survival rate using Equation 1. Approximately 1666.6 plots per hectare would represent typical garlic production practices.
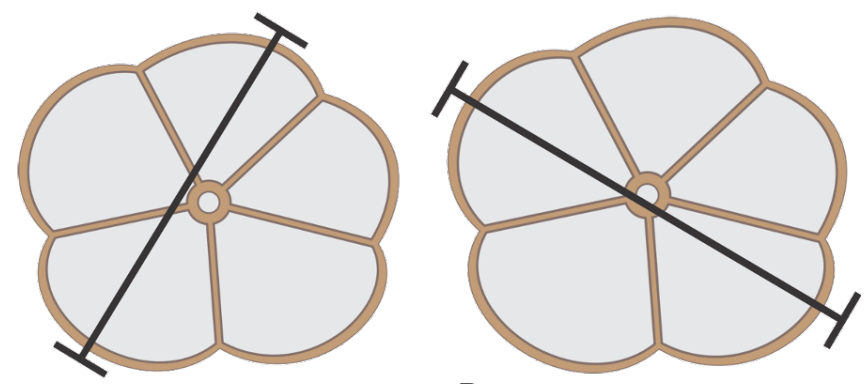

A.

B.

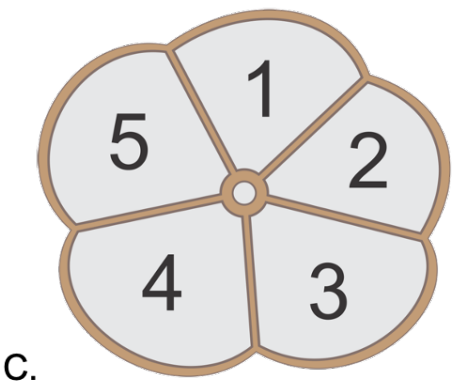

Figure 5: Diagrams representing the measurements of bulb characteristics. A. Minimum diameter across bulb. B. Maximum diameter across bulb. C. Clove count per bulb.

\section{Statistical Analyses}

Data was analyzed using single factor ANOVA at $\alpha$ $\leq 0.05$ with treatments as fixed effects and replicates as random effects. In agronomy, it is important to consider that real effects may be detected at the $\alpha \leq 0.10$ value; therefore, when $\mathrm{P}$-values were found to be greater than 0.5 but less than 0.10 , the effect was probed further and considered significant at the $\alpha \leq 0.10$ level. T-tests were conducted to determine differences between treatments. All statistical calculations were conducted using Microsoft Excel for Office 365 .

\section{Results}

\section{Weed Control and Mulch Damage}

During the winter of the experiment, wildlife, primarily elk (Cervus elaphus spp. nelsoni), damaged the mulches by perforating the mulch surfaces (Figure 5). Due to this damage, weeds were able to grow in the exposed spaces. However, there was no difference in elk damage across the treatments $(P=0.133$; Figure 6$)$ and, therefore, viable treatment comparisons were still applicable.

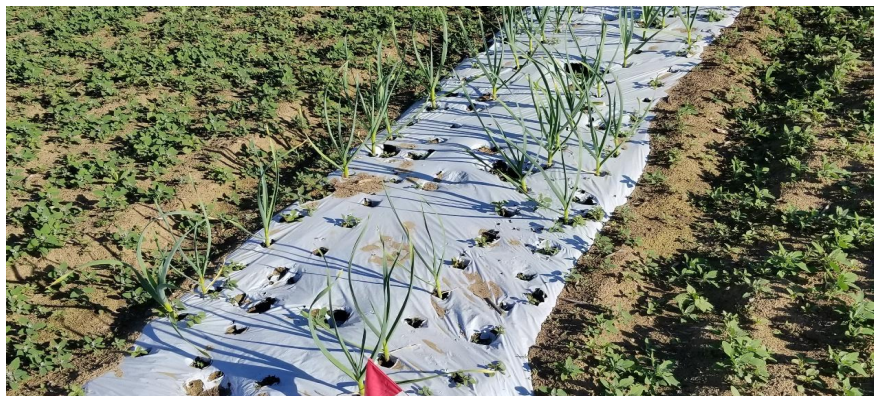

Figure 4: Mulch damage due to winter elk traffic. Photo credit M. Carr; May 21, 2018. 


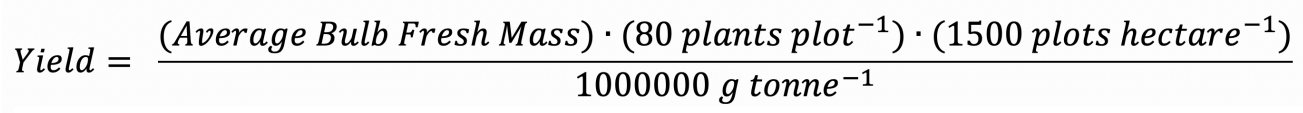

Equation 1: Yield $\left(\mathrm{Mg} \mathrm{ha}^{-1}\right)$ calculation.

In-season weed density was influenced by mulch treatments (Figure 7, P=0.0663). The control treatment with no mulch showed the highest average density of weeds per transect. White plastic mulch showed the lowest density of total weeds. Weed control in plastic mulches was significantly greater than the Kraft paper and control treatments. White plastic was significantly better at controlling weeds than black plastic.

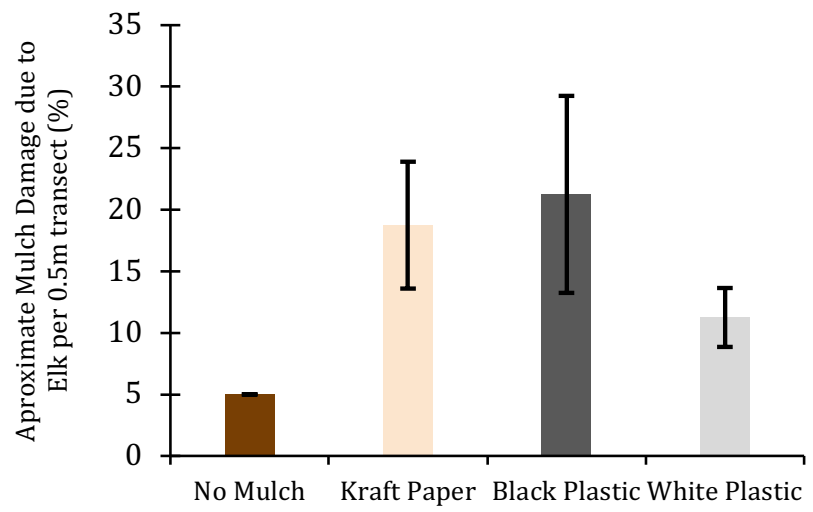

Figure 6: The comparison of approximate percentage of mulch damage due to elk between treatments within randomized $0.5 \mathrm{~m}$ transects $(P \geq 0.05)$. This estimate was based on visual percentage of damage to the mulch or hoofprints in the soil within the $0.5 \mathrm{~m}$ transects per plot where weed data was collected.

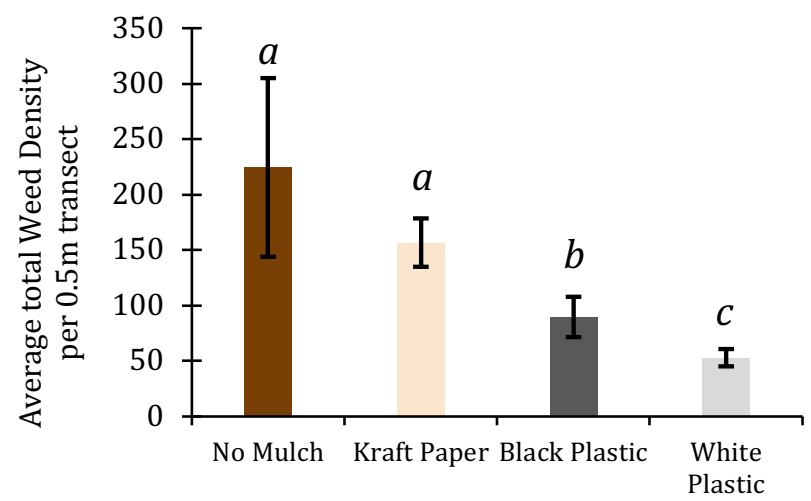

Figure 7: The comparison of total weed population between mulch treatments of randomized $0.5 \mathrm{~m}$ transects. Bars with different letters are significantly different $(P=$ 0.0663 ). This data is based on total weed counts per $0.5 \mathrm{~m}$ transect to demonstrate the weed reduction in each treatment.

Annual weeds such as lambsquarters (Chenopodium album L.) and redroot pigweed (Amaranthus retroflexus L.) were observed as the predominant weeds in the testing plot prior to our study, which is typical of most commercial vegetable fields in BC. This was consistent with the collected weed populations in Figure 8. It is interesting to note that there were consistently larger pigweed populations than lambsquarters in the control, black plastic and white plastic, with the exception of Kraft Paper.

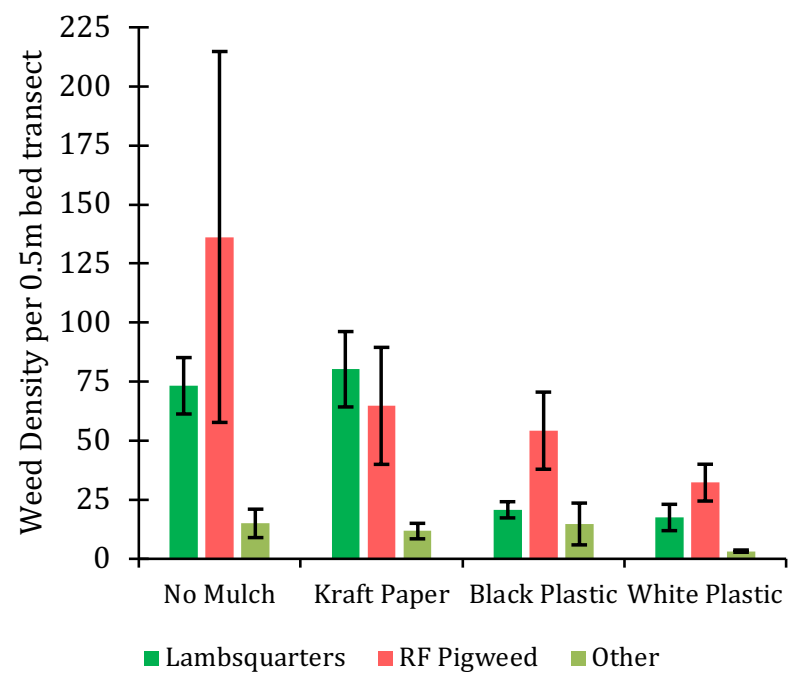

Figure 8: The comparison of weed density between treatments within randomized $0.5 \mathrm{~m}$ transects.

The dry weed biomass did not significantly differ between treatments (Figure 9). However, when we analyzed the dry weed biomass by the density of the total weed population, an interesting pattern occurred between the plastic mulches and the other treatments: black and white plastic had significantly larger weeds by dry biomass compared to Kraft paper and the control (Figure 10).



Figure 9: The average dry weed biomass compared among mulch treatments. Dry biomass was not significantly different between mulches and control $(P \geq 0.05)$. 


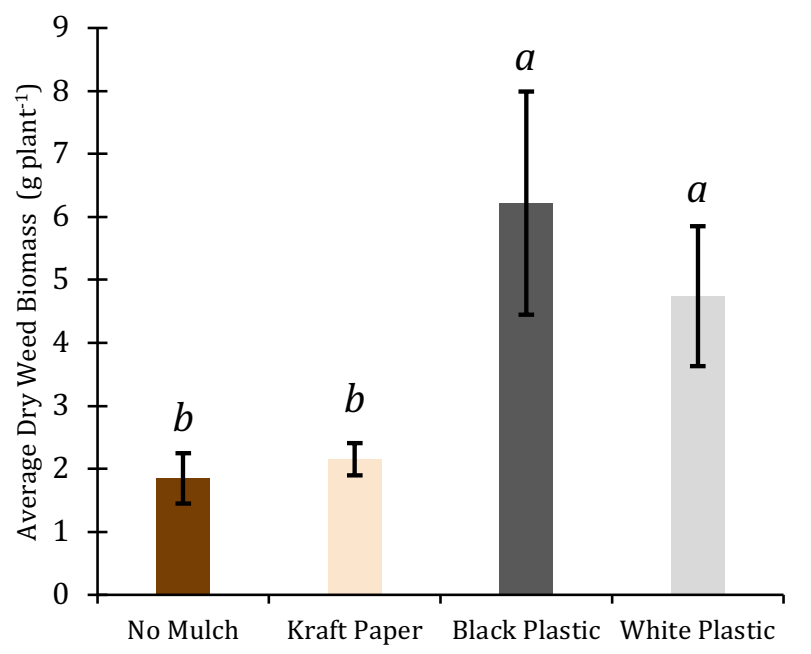

Figure 10: The average dry weed biomass per plant compared across mulch treatments. Bars with different letters are significantly different $(P=0.0387)$. Individual weeds were mulch larger in plastic mulch treatments than in the control and Kraft paper.

\section{Soil Temperature and Mineral Nitrogen}

White plastic had the lowest average soil temperature consistently, except for on June 7 (Table 4). Black plastic typically showed higher soil temperatures than the other treatments. The control was the most variable, ranging from the highest to lowest average soil temperature, depending on the sample day. The soil temperature results are interpreted based on patterns, as a more robust dataset of soil temperature recordings is required for proper statistical analyses.

Mulching did not influence the soil nitrate- $\mathrm{N}$ concentrations at harvest (Figure 11). On average, the difference between soil nitrate- $\mathrm{N}$ at pre-plant and harvest indicates that 59.5 to $64.4 \mathrm{~kg} \mathrm{ha}^{-1} \mathrm{NO}_{3}$ was removed from the soil by plant uptake, lost from the sampling zone, or turned

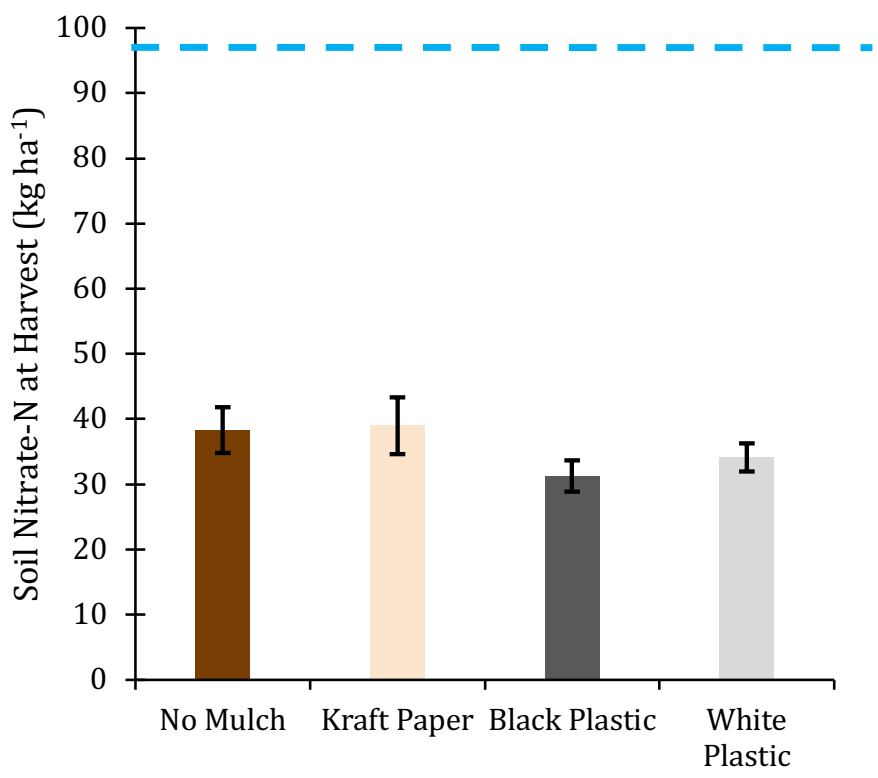

Figure 11: Soil nitrate- $\mathrm{N}$ contents in the top $15 \mathrm{~cm}$ depth at pre-plant (blue line) and at garlic harvest (bars). There was no difference between soil nitrate- $\mathrm{N}$ contents among mulch treatments at garlic harvest $(P \geq 0.05)$.

over and immobilized by microbes. These $\mathrm{N}$ pools were not measured.

\section{Bulb Characteristics}

Plastic mulches significantly increased the minimum bulb diameter compared to the control (Figure 12). Paper mulch had significantly larger minimum bulb diameter than the control but was not as significant as the plastic mulches. The control without mulch had the smallest minimum bulb diameter among treatments. Contrastingly, the average maximum bulb diameter followed a similar trend. The maximum bulb diameter was the largest in white plastic mulch. Plastic and Kraft paper mulches had significantly larger bulb diameters than the control (Figure

Table 4: Average soil temperatures per date compared across mulch treatments.

\begin{tabular}{|c|c|c|c|c|c|}
\hline \multirow[b]{2}{*}{ Treatments } & \multicolumn{5}{|c|}{ Average Soil Temperature $\left({ }^{\circ} \mathrm{C}\right)$} \\
\hline & $\begin{array}{l}\text { Date } \\
\text { Time } \\
\end{array}$ & $\begin{array}{l}\text { May } 21 \\
\text { 7:00 pm }\end{array}$ & $\begin{array}{c}\text { June } 4 \\
\text { 7:00 pm } \\
\end{array}$ & $\begin{array}{c}\text { June } 7 \\
\text { 5:00 pm } \\
\end{array}$ & $\begin{array}{l}\text { July } 13 \\
\text { 7:00 pm }\end{array}$ \\
\hline No Mulch & & 26.7 & 21.4 & 22.8 & 34.9 \\
\hline Kraft Paper & & 26.5 & 21.4 & 25.0 & 33.3 \\
\hline Black Plastic & & 26.7 & 21.9 & 25.5 & 33.8 \\
\hline White Plastic & & 24.9 & 21.1 & 23.5 & 32.7 \\
\hline
\end{tabular}


13). Interestingly, the comparison of the minimum and maximum diameters was insignificant across treatments (Figure 14), indicating that the shape of the bulbs was not influenced by the mulch.

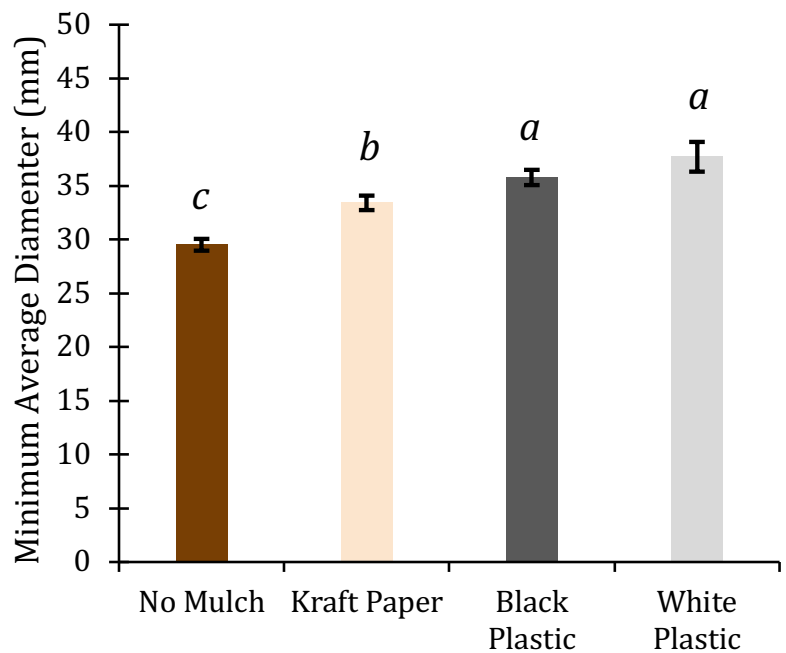

Figure 12: Average minimum bulb diameter of 20 randomized bulbs per plot between treatments. Bars with different letters are significantly different $(P=0.0006)$.

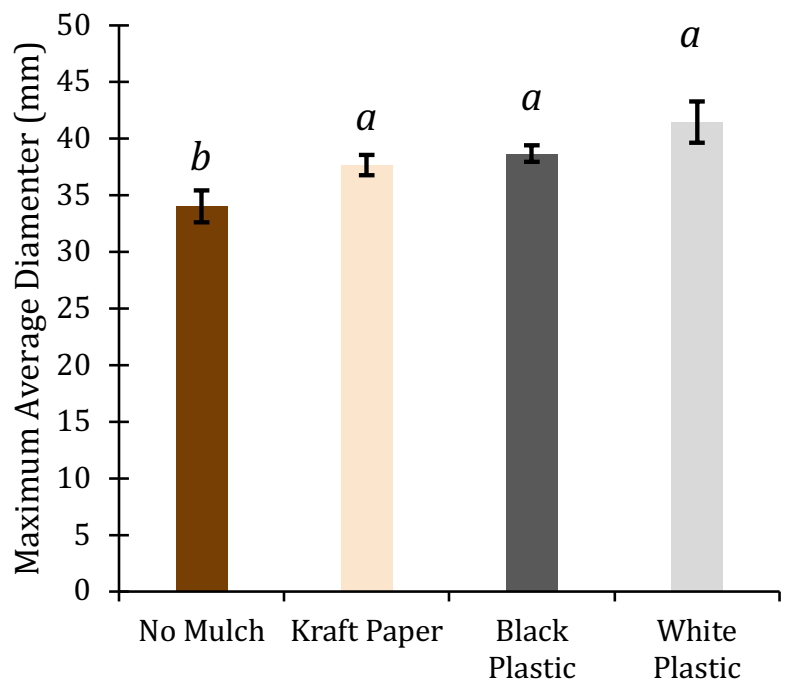

Figure 13: The comparison of average maximum bulb diameter of 20 randomized bulbs per plot between treatments $(P=0.0173)$.

The clove counts were influenced by mulches, which significantly increased the number of cloves per bulb (Figure 15). White plastic produced bulbs with a higher number of cloves compared to paper; however, black plastic was comparable to both white plastic and paper. Although clove count could be considered low, they are within the typical range for the cultivar ( 4 to 7 cloves per bulb).

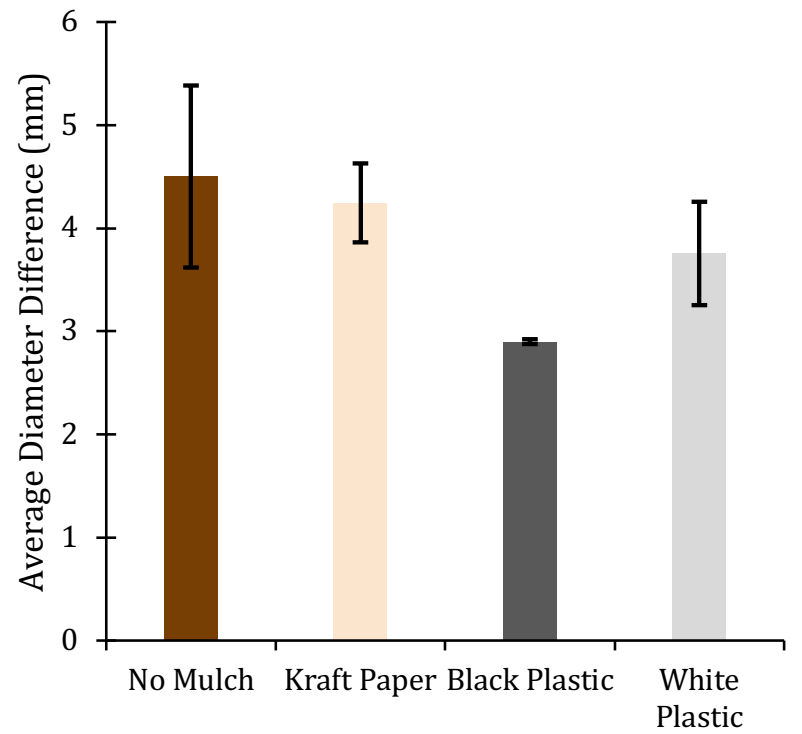

Figure 14: The average difference in diameters of 20 randomized bulbs per plot, between treatments $(P \geq 0.05)$.



Figure 15: The average clove count per bulb for 20 randomized bulbs per plot, compared across treatments. Bars with different letters are significantly different $(\mathrm{P}=0.0052)$.

\section{Yield}

Average yields in the mulched treatments were within the Canadian average yield range of 2 to $4 \mathrm{Mg} \mathrm{ha}^{-1}$ (as noted by the blue line in Figure 16). Our mulch treatments influenced garlic yields $(\mathrm{P}=0.0680)$. White plastic, black plastic, and paper mulch garlic yields were not significantly different, but all were higher than the control without mulch. The control treatment without mulch had the lowest yields, which were below the Canadian average. White plastic 
represented the highest yields among the mulched treatments, although they were statistically similar.

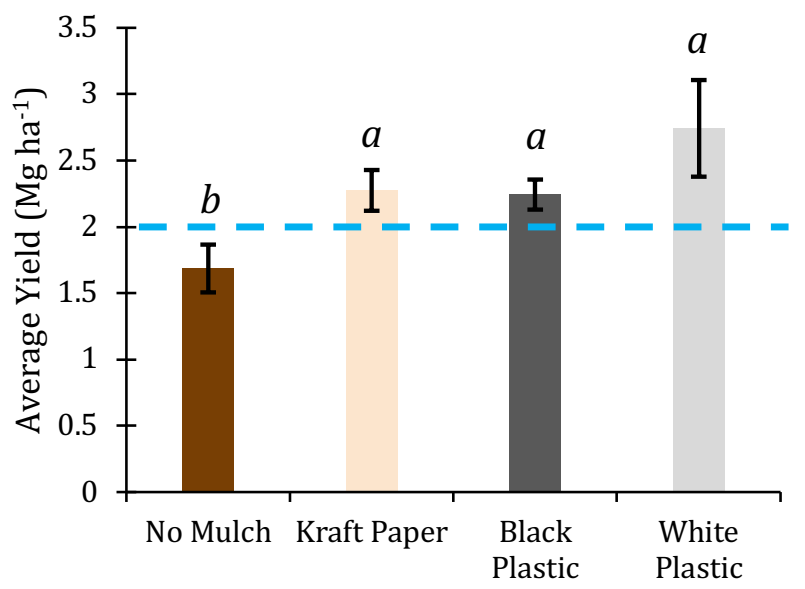

Figure 16: Average yield, $\mathrm{Mg} \mathrm{ha}^{-1}$, compared between treatments. Bars with different letters are significantly different, $P=0.0680$. The blue line indicates the lower boundary of the Canadian average garlic yield per hectare.

\section{Discussion}

\section{The Benefits of Mulching}

The results of the study illustrate that mulching systems can influence garlic production in organic systems. Weed control was most likely impacted by mulch type; specifically, better weed suppression may be expected using white and black plastic mulches compared to the control and Kraft paper, despite winter mulch damage. The plastic mulches tended to have fewer weeds, but they were larger compared to the Kraft paper and control, signalling that growing conditions may have been better with plastics for both the weeds and the crop. Soil temperatures fluctuated between mulch treatments, as seen in other studies (Ham et al. 1993; Lamont 2005; Snyder et al. 2015). Our study did not analyze soil temperature fluctuation due to limited resources.

Soil nitrate use or loss was consistent among mulch types at harvest, indicating that mulching did not impact soil nitrate in the top $15 \mathrm{~cm}$. More frequent soil sampling is needed to determine if and how mulching influences soil $\mathrm{N}$ cycling dynamics through the winter or during the growing season. Earlier studies found that reduced nitrogen (Kasirajan and Ngouajio 2012; Domagała-Światkiewicz and Siwek 2013) and accelerated organic matter decomposition (Steinmetz et al. 2016) in the plastic mulches may provide the garlic with more available nitrogen to increase biomass and yields. This theory could potentially explain why the plastic mulches had higher quality characteristics and improved yields compared to the Kraft paper and control treatments. Determining plastic and paper mulch effects on soil carbon would add to our understanding of soil nutrition. In theory, plastic mulches should lead to lower carbon levels due to the accelerated biodegradation in the soil (Steinmetz et al. 2016), and paper may improve soil carbon by degrading into the soil. Further research is warranted in this area.

Mulches can evidently provide returns for growers. Table 5 demonstrates the potential economic improvement for both seed and culinary production. For seed growers, minimum diameter is one of the most important factors in determining grade, which influences price per bulb. Minimum bulb diameter may be increased from $13 \%$ to $28 \%$ by growing in a synthetic mulch. We see a similar trend where yield weight may be increased by $33 \%$ to $63 \%$ when using mulches. The yield calculation is important for both seed and culinary producers. When calculated, this mulchinduced increase in yield can translate to greater grower returns per hectare of $\$ 5,000$ or more. With our results, we can effectively see a pattern of improved yields and increased grower returns when growing with a synthetic mulch for garlic production.

Table 5: Comparison of production improvements for grower returns.*

\begin{tabular}{ccccc}
\hline Mulch & $\begin{array}{c}\text { Minimum } \\
\text { Diameter } \\
\text { Increase (\%) }\end{array}$ & $\begin{array}{c}\text { Yield Weight } \\
\text { Increase (\%) }\end{array}$ & $\begin{array}{c}\text { Gross Return } \\
\text { ha }^{-1} \text { at } \$ 5 \mathrm{~kg}^{-1}\end{array}$ & $\begin{array}{c}\text { Change in Gross } \\
\text { Return ha }\end{array}$ \\
\hline Control & & & $\$ 8427.50$ & \\
Kraft Paper & 13.2 & 34.9 & $\$ 11,371.95$ & $+\$ 2,944.45$ \\
Black Plastic & 21.2 & 33.1 & $\$ 11,214.15$ & $+\$ 2,786.65$ \\
White Plastic & 27.7 & 62.7 & $\$ 13,710.23$ & $+\$ 5,282.73$ \\
\hline F Future research will be needed to confirm results & & & \\
a. Gross profit accounting for 10\% crop loss & & &
\end{tabular}


Paper Mulch as an Alternative to Plastic Mulch

Paper mulch may be an alternative mulch for organic growers looking to avoid labour costs associated with removing annual plastic mulch films from their fields. Our results show that the Kraft paper mulch positively influences garlic production, although this influence on production is not as substantial as plastic mulches. Regardless, it is important to note the potential viability of Kraft paper as a synthetic mulch.

Even though the weed control was not as significant as black or white plastics, Kraft paper showed lower, but not statistically significant, weed densities compared to control with no mulch. The deterioration rate for Kraft paper mulches can impact weed densities, posing a challenge for use with biennial crops, like garlic. In our treatments, the Kraft paper started to break down as soon as the snow melted in the spring, leaving cracks where weed seedlings could penetrate. The garlic was able to penetrate through the paper when it was wet during snowmelt; however, we did not notice any weeds growing through the mulch after it had dried. A thicker paper mulch may have the potential to withstand degradation longer but may also be harder to apply in the field, as thicker material is more cumbersome to transport and apply. The development of an organic treatment to the paper to slow much deterioration could be another solution.

Soil attributes could be altered by Kraft paper mulch, although this experiment was unable to test all of these factors sufficiently. Previous studies have found that paper mulches tend to reduce soil temperatures, are permeable to moisture, and may retain soil moisture longer than no mulch (Schonbeck and Evanylo 1998; Coolong 2010; Saglam et al. 2017). As such, paper mulch might enable more infiltration of rainfall than plastic mulch (however, most operations use irrigation regardless of mulch type). Our results show that the Kraft paper could decrease the soil temperatures, which is consistent with Schonbeck and Evanylo's report (1998). Permeability was not tested in this experiment, but we assumed that water penetrated through the paper, due to paper saturation in the early spring. The degradation of the paper mulch may also influence water penetration and retention in the soil. Large gaps in the paper allowed weeds to grow and could also alter the water movement into and out of the soil. As mentioned previously, a thicker paper material or a paper treatment to increase strength or slow degradation may reduce water permeability into the soil but would dramatically improve the soil water retention. We were interested in determining if the mulch would immobilize excessive amounts of nitrogen from the soil as the paper degraded while the garlic was growing, but no significant changes in nitrogen removal throughout the season.

In most aspects, bulb characteristics improved with the use of Kraft paper mulch. The maximum average diameter was comparable to both plastic mulches. The minimum average bulb diameter increased compared to the control, but it was not as significant as the plastic mulches. The minimum bulb diameter is more important for final bulb grading, and although the increase was not as great as plastic mulches, the Kraft paper has the potential to improve grade sizing and influence profits. Similarly, clove count increased with the use of Kraft paper compared to control. The increase was not as substantial as white plastic but was comparable to black plastic. These improvements enforce the potential use of Kraft paper as a mulch in similar garlic production.

The overall garlic yield was likely improved by Kraft paper mulch. In our trial, the Kraft paper treatment yields were similar to both plastic mulches, indicating its potential viability as an alternative mulching method to plastic films. Since the weed control of the Kraft paper was worse than the plastic mulches, but overall yields were statistically similar between all synthetic mulches, weed control was most likely not the only factor influencing the trial. Decreased soil temperature may have allowed the garlic to grow larger before the requirements of bulb initiation are met (Jones and Mann 1963; Wu et al. 2015, 2016a, 2016b). Water permeability could affect the yield by allowing natural precipitation to provide moisture while irrigation was unavailable. Developing a renewable and biodegradable alternative to plastic mulches is important for growers, and we have found that Kraft paper is a viable alternative.

\section{Black Plastic Mulch is the Industry Standard - but Should it be for Garlic?}

Our experiment supports earlier work that demonstrates the positive impacts of plastic mulching on garlic production, but our results call into question whether black plastic offers the most benefits for growers.

While weed control was greatly improved in the black plastic treatment compared to the control, the white plastic mulch had the best weed control-most likely due to the opaque plastic acting as a physical barrier and light limitation to suppress weed germination and growth (Snyder et al. 2015). Complete weed control was not achieved due to damage caused by elk traffic over the winter. The flexibility of the material was not able to withstand the weight of the elk, causing easily distinguishable perforations that allowed weed growth to occur (Figure 2). Similarly, the plastic mulch was perforated using a dibbler to create planting holes. These holes allowed weeds to grow very close to the bases of each plant, dramatically increasing competition for resources. Weeds around the plants are usually inevitable in organic production but are easy to control with one or two manual weeding sessions while the weeds are young (approximately less than $10 \mathrm{~cm}$ ).

It was predicted that black plastic mulch would increase the soil temperature compared to the other 


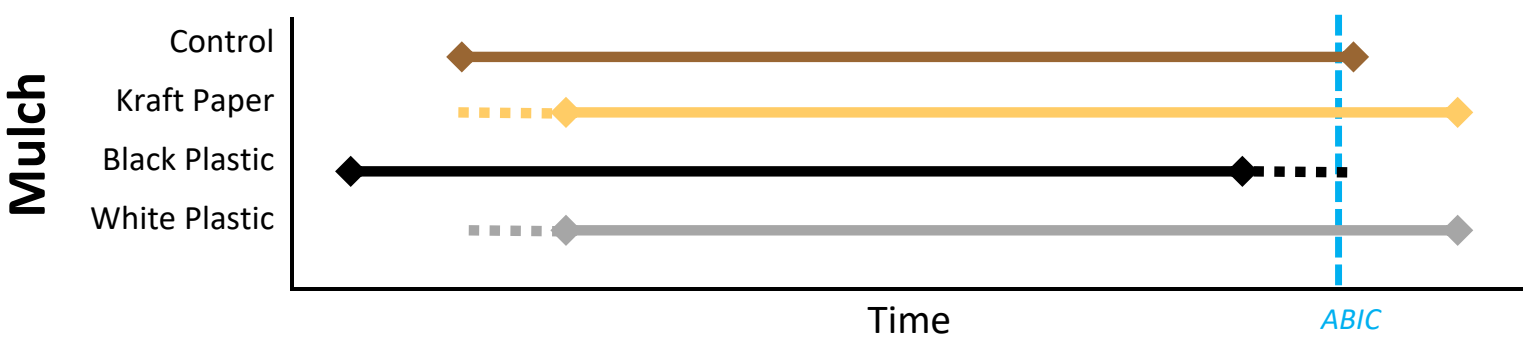

Figure 17: Potential growth periods before bulb initiation influenced by mulch type. The horizontal solid lines indicate the expected growth periods before bulbing. The horizontal dotted lines indicate potential seasonal variation, which may affect the length of the growth period before bulbing. The blue vertical dotted line indicates when average bulb initiation conditions (ABIC) occur, stopping biomass growth that will influence yield. The figure is not to scale and is only for representation of the alteration of potential growth periods.

mulches and control (Snyder et al. 2015). However, we were unable to test this phenomenon effectively. A computerized soil temperature logger would have been able to accurately measure the temperatures throughout the season, showcasing the fluctuations and timing of potential influences. With the goal of increasing the garlic biomass before bulb initiation conditions, black plastic could increase the soil temperature earlier in the season, extending the growth period. The soil temperature modification of the black plastic may also decrease the growth period before bulbing by increasing the soil temperatures past the $20^{\circ} \mathrm{C}$ threshold earlier in the season (Figure 17, Wu et al. 2015, 2016b).

The overall yield was comparable among the synthetic mulches. The average yields were comparable between the treatments, but the weed control for black plastic was better than for Kraft paper. Therefore, it is most likely that weed control is not the only influential factor for improving garlic production. We observed benefits in producing garlic with white plastic mulch compared to black plastic mulch-economic benefits (Table 5), weed control (Figure 7), or numerically higher yields (Figure 16). These trends may have been a result of soil temperatures reaching bulb initiation levels earlier, leading to a reduced potential growing period before bulb initiation and later biomass accrual. In contrast to black plastic, white plastic mulches typically reduce soil temperatures by reflecting solar energy away from the soil (Snyder et al. 2015). Although our soil temperature sampling was insufficient for statistical analysis, white plastic often had lower soil temperatures, similar to the results found by Snyder et al. (2005). This result is important because soil temperatures are influential in initiating bulbing in garlic (Wu et al. 2015, 2016b). It is expected that the soil would warm slower, lengthening the growing period before bulb initiation to a greater degree than the other treatments (Figure 17). By increasing the growing period before bulbing, the plant may be able to divert more resources to biomass accrual, which correlates with increased final yield (Jones and Mann 1963). Figure 17 graphically illustrates the comparable difference in the extension of the growing season before bulbing between mulches.

The garlic yield data collected from all synthetic mulch treatments were within the Canadian average yield per hectare for garlic. Although further yield increases could still be achieved, reportedly up to 10 tonnes per hectare ("Saskatchewan Ministry of Agriculture" n.d.), the yield results from our study are representative. White plastic mulch looks to be the best option for growers in warmer climates that are looking to efficiently alter soil conditions to increase garlic production and subsequent grower returns.

\section{Future Areas of Research}

Weed control was likely not the only factor influencing yields. Soil modifications appear to play a significant role in influencing garlic production. By using technology over multiple seasons, such as computerized temperature and moisture data loggers, future studies will be able to determine the best mulching practices for organic garlic production more accurately. More attention to the crop growth rates and staging/maturity dates may also be useful in determining a final recommendation for growers. Increasing the length of the study would decrease any affecting errors from year to year and seasonal climatic conditions.

Kraft paper could be an alternative to plastic mulches for growers who would prefer a biodegradable material for mulching, with opportunities for further research in material characteristics. In our results, Kraft paper was often similar to black plastic, so paper-based mulch could be a suitable alternative. Soil modifications of Kraft paper are expected to be similar to white plastic but are not currently as effective due to degradation during the cropping season that exposes more soil surface area, reducing soil temperature modification and allowing more weeds to grow. Soil moisture may also be difficult to control 
as the Kraft paper mulch is much more permeable than plastic films, which may be important during specific stages of the crop, such as field drying before harvest. The cost of the Kraft paper and the more difficult application method are other factors that may influence growers' acceptance of paper mulching material. Future study into different paper materials, such as thickness or treatments to increase strength and limit breakdown, would be useful to confirm our initial results.

To conclude, growers can expect improved agronomic traits and increased returns by using synthetic mulches to improve their garlic production. White plastic mulch is the most effective and efficient option for the majority of growers. Kraft paper has the potential to become a serious competitor with plastic mulches in an organic garlic production system, but more research and development is required before large-scale adoption would be possible. Because the scope of our study is limited to one area, future work should encompass a wider variety of climatic soil conditions in various garlic-producing regions.

\section{Acknowledgements}

The authors are grateful to the College of Agriculture and Bioresources Department of Plant Sciences for supporting this research as part of PLSC 494.6. Special thanks to the Congreves' lab group, including technicians and graduate and undergraduate students, for their support in the lab and in discussing data presentation. 


\section{Literature Cited}

Coolong, T. 2010. Performance of paper mulches using a mechanical plastic layer and water wheel transplanter for the production of summer squash. Horttechnology 20: 319-324.

Domagała-Światkiewicz, I., and Siwek, P. 2013. The effect of direct covering with biodegradable nonwoven film on the physical and chemical properties of soil. Polish J. Environ. Stud. 22: 667-674.

Engeland, R.L. 1991. Growing Great Garlic. Filaree Productions, Okanogan, WA.

Ham, J.M., Kluitenberg, G.J., and Lamont, W.J. 1993. Optical Properties of Plastic Mulches Affect the Field Temperature Regime. 118: 188-193. doi:http://journal.ashspublications.org/content/118 /2/188.short.

Hutchins, A.E. 1933. Mulch paper in Vegetable production. Minnesota.

Jones, A., and Mann, L.K. 1963. Onions and their allies: botany, cultivation, and utilization. Interscience Publishers, New York.

Kasirajan, S., and Ngouajio, M. 2012. Polyethylene and biodegradable mulches for agricultural applications: A review. Agron. Sustain. Dev. 32: 501-529. doi:10.1007/s13593-011-0068-3.

Lamont, W.J. 2005. Plastics: Modifying the microclimate for the production of vegetable crops. Horttechnology 15: 477-481.

Maynard, D.G., Kalra, Y.P., and Crumbaugh, J.A. 2008. Nitrate and Exchangeable Ammonium Nitrogen. Pages 71-80 in M.R. Carter and E.G. Gregorich, eds. Soil Sampling and Methods of Analysis Second Edition. Taylor \& Francis Group, Boca Raton, FL.

Saglam, M., Sintim, H.Y., Bary, A.I., Miles, C.A., Ghimire, S., Inglis, D.A., and Flury, M. 2017. Modeling the effect of biodegradable paper and plastic mulch on soil moisture dynamics. Agric. Water Manag. 193: 240250. doi:10.1016/j.agwat.2017.08.011.

Saskatchewan Ministry of Agriculture (n.d.). [Online] Available:

https://www.saskatchewan.ca/business/agriculture -natural-resources-and-industry/agribusiness- farmers-and-ranchers/crops-and-

irrigation/horticultural-crops/vegetables/garlic [2019 Nov. 6].

Schonbeck, M.W. 2008. Weed Suppression and Labor Costs Associated with Organic, Plastic, and Paper Mulches in Small-Scale Vegetable Production. J. Sustain. Agric. 13: 13-33. doi:10.1300/jo64V13no2_04.

Schonbeck, M.W., and Evanylo, G.K. 1998. Journal of Sustainable Agriculture Effects of Mulches on Soil Properties and Tomato Production I. Soil Temperature, Soil Moisture and Marketable Yield Effects of Mulches on Soil Properties and Tomato Production I. Soil Temperature, Soil Moisture and Marke. J. Sustain. Agric. 13: 55-81. doi:10.1300/Jo64V13no1_06.

Snyder, K., Grant, A., Murray, H., and Wolff, B. 2015. The effects of plastic mulch systems on soil temperature and moisture in central Ontario. Horttechnology 25: 162-170.

Steinmetz, Z., Wollmann, C., Schaefer, M., Buchmann, C., David, J., Tröger, J., Muñoz, K., Frör, O., and Schaumann, G.E. 2016. Plastic mulching in agriculture. Trading short-term agronomic benefits for long-term soil degradation? Sci. Total Environ. 550: 690-705. Elsevier B.V. doi:10.1016/j.scitotenv.2016.01.153.

Walters, S.A. 2008. Production method and cultivar effects on garlic over-wintering survival, bulb quality, and yield. Horttechnology 18: 286-289. American Society for Horticultural Science.

Waterer, D. 2010. Evaluation of biodegradable mulches for production of warm-season vegetable crops. Can. J. Plant Sci. 90: 737-743. doi:10.4141/CJPS10031.

Waterer, D., and Schmitz, D. 1994. Influence of variety and cultural practices on garlic yields in Saskatchewan. Can. J. Plant Sci. 74: 611-614. doi:https://doi.org/10.4141/cjps94-110.

Waterer, D.R. 2000. in a Cool Climate. Horttechnology 10: 154-159.

Wu, C., Wang, M., Cheng, Z., and Meng, H. 2016a. Response of garlic ( Allium sativum L.) bolting and bulbing to temperature and photoperiod treatments. Biol. Open 5: 507-518. doi:10.1242/bio.016444. 
Wu, C., Wang, M., Dong, Y., Cheng, Z., and Meng, H. 2015. Growth, bolting and yield of garlic (Allium sativum L.) in response to clove chilling treatment. Sci. Hortic. (Amsterdam). 194: 43-52. doi:10.1016/j.scienta.2015.07.018.

Wu, C., Wang, M., Dong, Y., Cheng, Z., and Meng, H. 2016b. Effect of plant age and vernalization on bolting, plant growth and enzyme activity of garlic (Allium sativum L.). Sci. Hortic. (Amsterdam). 201: 295305. doi:10.1016/j.scienta.2016.02.006. 
Synthetic Mulch Influence on Garlic Production (Carr)

University of Saskatchewan Undergraduate Research Journal 